UDC $811.124+81-16+81-24$

\title{
Latin Case System: \\ Towards a Motivated Paradigmatic Structure
}

\author{
Elena V.Zheltova
}

St. Petersburg State University,

7-9, Universitetskaya nab., St. Petersburg, 199034, Russian Federation; e.zheltova@spbu.ru

\section{Alexander Ju. Zheltov}

St. Petersburg State University,

7-9, Universitetskaya nab., St. Petersburg, 199034, Russian Federation; a.zheltov@spbu.ru;

Peter the Great Museum of Anthropology and Ethnography (Kunstkamera),

3, Universitetskaya nab., St. Petersburg, 199034, Russian Federation; azheltov@kunstkamera.ru

For citation: Zheltova E. V., Zheltov A. Ju. Latin Case System: Towards a Motivated Paradigmatic Structure. Philologia Classica 2020, 15 (2), 208-229. https://doi.org/10.21638/spbu20.2020.203

The article attempts, firstly, to critically analyze the traditional order of cases in Latin, secondly, to discover an internal mechanism that brings the elements of a paradigm together, and thirdly, to present a new model of the nominal and pronominal case paradigms in Latin. The authors develop the idea that the crucial role in structuring a case paradigm belongs to morphemic syncretism. The syncretism is treated as a systemic phenomenon of morpheme neutralization rather than a result of phonetic reduction. In the paradigm built on this principle, the cases marked with the same endings necessarily take adjacent positions. There is a certain correlation between the morphemic syncretism and the semantics of cases extensively exemplified in the Latin literature. Taking this as reference point, the authors establish a formally motivated paradigmatic order of cases and single out a set of semantic features that shape the case paradigm. This method enables authors to find the non-contradictory paradigmatic positions for both the core and the "marginal" cases (vocative and locative). Applied to the pronominal cases, however, it reveals the significant discrepancy between the nominal and pronominal paradigms concerning two cases - nominative and genitive. The pronominal nominative's special status is determined by its pragmatic rather than syntactic functions, which is typical for pro-drop languages. The genitive case appears in three different forms that originate from the possessive pronouns and correspond to the three basic functions of the genitive - possessive, objective, and partitive ones. Such transparadigmatic syncretism brings together the paradigms of personal and possessive pronouns, which are related by nature. The

(C) St. Petersburg State University, 2020 
approach suggested in this study makes it possible to present in a new way the nominal and pronominal case paradigms, to demonstrate in what points they differ from each other, and to highlight some functional and semantic features of the particular cases.

Keywords: Latin, case paradigm, nominal and pronominal cases, syncretism, morphemic neutralizations, paradigmatic oppositions.

\section{State of the $\operatorname{art}^{1}$}

In the long tradition of describing the Latin case system, one can find only three patterns of ordering cases in the paradigm, which slightly differ from each other. The main tradition that goes back to the ancient Greek grammarians ${ }^{2}$ and was borrowed by the Romans (with the addition of ablative), puts the cases in the following order: nominative, genitive, dative, accusative, vocative, ablative. A later version of this tradition (see in particular Wheelock's Latin, 11) moves the vocative to the end of the list. The third pattern has been put forward by Kennedy $(1972,5)$ "to facilitate memorizing": nominative, vocative, accusative, genitive, dative, ablative.

If we start from the original meaning of the word "paradigm" 'example, sample' and pursue only didactic purposes, the question of the case order seems insignificant. If, however, one considers the term "paradigm" from the linguistic standpoint, which goes back to the Saussure's opposition of syntagmatic and associative relations and implies the paradigm structuring of the elements (Saussure 1977, 155-156), ${ }^{3}$ then several questions arise:

1) why should the elements of the language subsystem - which paradigm really is - be listed horizontally or vertically?

2) what should paradigm look like?

3) what means do connect and distinguish its elements?

4) which of the elements are closer to each other within the framework of associative (paradigmatic) relations?

There is one more problem, which turned out to skip the descriptive grammars' attention: what is the reason for syncretism (homonymy) of a large number of the Latin case inflections? The concept "one form - one meaning" is not applicable to the Latin cases, although the potential of any phonological system seems sufficient to develop different forms for all meanings relevant to a particular language. Why is this potential never used even for a minimal set of the elements, which the case paradigm is? Why, on the contrary, the language admits creating a lot of syncretic forms, which works against the criteria of

1 The first part of this study was presented at the conference Indoeuropean Linguistics and Classical Philology - XXIV, St. Petersburg, 2020 (Zheltov, Zheltova 2020 (Желтов А. Ю., Желтова Е. В. Почему язык «экономит» на падежных флексиях, или к вопросу о порядке падежей в латыни. Индоевропейское языкознание и классическая филология 2020, 24 (2), 1040-1069)). We are indebted to N. N. Kazansky, A. Ju. Rusakov, S. G. Bolotov and M. M. Pozdnev for their valuable advice.

2 Dionysius Thrax singled out the following noun cases in the Greek language: direct (or nomina-

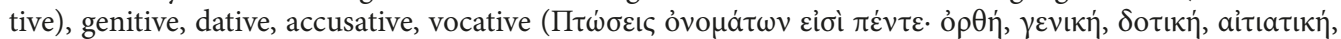

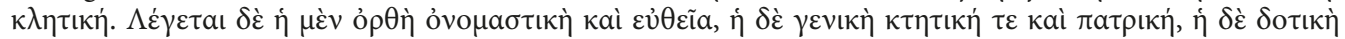

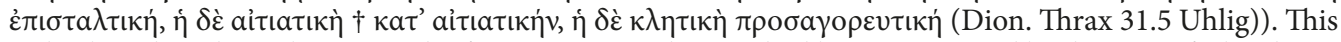
order, based on the earlier research of peripatetics and stoics, had been recognized by the time of Cleochares of Myrlea (amid the $3^{\text {rd }}$ c. BC), as Barwick, with reference to Wackernagel, points out (Barwick 1933, 593594). On the early history of the term 'declension' and the case lables, see Blake 2001, 18-19; 2008, 13-16.

${ }^{3}$ Соссюр Ф. Труды по языкознанию. М.: Прогресс, 1977. 
unambiguity? Explaining syncretism by the "principle of economy" does not solve the problem: the question remains why the language in some cases saves on linguistic material while in others (for example, in the case of synonymy), it admits redundancy. The phonetic reduction process may be a reasonable explanation for some cases but does not answer why some forms are reduced (or are reduced earlier than others) while others are not.

These challenging questions do not find answers within the framework of the Latin case system and beyond, although the attepmts have been made since at least the $18^{\text {th }}$ century. It was Rasmus Kristian Rask who devoted most attention to the question of the case order. He was almost haunted by a desire to restore the inflectional paradigms, especially of the Old Germanic tongues and of Latin and Greek, to their natural order. What is more, the Rask's quest really was for insight into the structure of language. His two main formal criteria were derivability and homonymy. The first criterion suggested the placement of 'derived' forms after their bases (e. g., accusatives after nominatives rather than after datives or genitives). ${ }^{4}$ The second one implied the neighbourhood of terms with similar exponents (Plank 1991, 169-170). Despite such insightful ideas, it is not earlier than in the $20^{\text {th }}$ century that this line of Rask's work was continued.

The reason, probably, is that the language system (la langue), unlike speech (la parole), can't be observed directly, and we still lack generally recognized methods of describing systemic paradigmatic relations, although the functions of the particular Latin cases in various syntagmatic contexts are described quite exhaustively (see e. g. Woodcock 1959; Hofmann, Szantyr 1972). The attempts to present cases as invariants of these functions, i. e. to find general definitions to cover all the contextual syntagmatic meanings, are not convincing. This is precisely what W. Royal has come up with in his "Treatise on Latin Cases and Analysis". Grounded on the philosophical concept that everything in nature, be it perceptible or conceivable, has a starting point, a direction (goal) of movement, an extension, and result, he presented each case as a carrier of one of the macrofunctions (Royal $1860,5)$. Thus, the genitive, as a 'causal element,' indicates the prime starting-point, the ablative ('sub-causal element') - the intermediate starting-point, the dative expresses the direction and purpose (object-point), and the accusative, as a limitation case, - the extent and result. The search for invariant case meanings seems to be the primary trend in the Latin case system's modern studies. ${ }^{5}$

It is to be stressed that paradigmatic description of the case system is especially difficult because "case is a category associated with almost all levels of the language: with morphology, since the case is a morphological category expressed with the help of morphemes; with syntax, since cases indicate, inter alia, the grammatical status of the constituents; with semantics, since cases express the semantic relations between the words within the clause" (Arkadiev 2009, 59). ${ }^{6}$ Analyzing the order of cases in the Russian declension system, Arkadiev, on the one hand, underlines its conventional character; on the other hand, he argues that the question of the order of cases is not entirely meaningless: since declension is a system, its structure may be mirrored by the layout of cases in a paradigm. $\mathrm{He}$, then, raises the question which order better reflects the internal structure of the Rus-

${ }^{4}$ Cf. the Latin $3^{\text {rd }}$ Pers. f. sing. demonstrative eam, best 'derived' from Nom. ea, rather than from the Gen. eius or Dat. ei (Plank 1991, 170).

${ }^{5}$ See, e. g., Serbat 1981a, b; Carvalho 1983; Blake 2001, 34-45.

${ }^{6}$ Аркадьев П. М. Падежи в языках мира, в: Е. В. Муравенко, А. Ч. Пиперски, О. Ю. Шеманаева (ред.) Лингвистика для всех: Летние лингвистические школы 2007 и 2008. М., 2009, 59-71. 
sian case system: the traditional (Nominative, Genitive, Dative, Accusative, Instrumental, Prepositional) or the alternative one (Table 1) (Arkadiev 2009, 62-63). ${ }^{7}$

Table 1. "Motivated" order of cases in Russian

\begin{tabular}{|c|c|c|c|c|}
\hline Case & $1^{\text {st }}$ decl. f. Sg. & $2^{\text {nd }}$ decl. m. Sg. & $2^{\text {nd }}$ decl. n. Sg. & $3^{\text {rd decl. f. Sg. }}$ \\
\hline Nominative & рука [ruka] & Hос $[$ nos $]$ & вино [vino] & пыль [pyl’] \\
\hline Accusative & руку [ruku] & нос [nos] & вино [vino] & пыль [pyl’] \\
\hline Genitive & руки [ruki] & носа [nosa] & вина [viná] & пыли [pyli] \\
\hline Partitive & руки [ruki] & (из) носу [iz nosu] & вина [viná] & пыли [pyli] \\
\hline Dative & руке [ruke] & носу [nosu] & вину [vinu] & пыли [pyli] \\
\hline Prepositional & (о) руке $[(\mathrm{o})$ ruke] & (o) носе $[(\mathrm{o})$ nose $]$ & (о) вине [(o) vine] & (o) пыли [(o) pyli] \\
\hline Locative & (в) руке [(v) ruke] & (на) носу [(na) nosu] & (в) вине $[(\mathrm{v})$ vine $]$ & (в) пыли [(v) pyli] \\
\hline Instrumental & рукой [rukoi] & носом [nosom] & вином [vinom] & пылью [pylju] \\
\hline
\end{tabular}

The first order is determined by the Greco-Roman tradition while the second one by the internal properties of the language, i. e. by the similarity of the case endings. Based on the analysis of the widespread homonymy of the Russian case forms, the author summarizes his observations as follows: "The traditional order places the same case forms far from each other: the nominative and accusative are separated by the genitive and dative, the dative and prepositional - by the accusative and instrumental, etc. On the contrary, in Table 1, the cases with the same endings are placed next to each other. This order, which has little in common with the traditional one, clearly reflects morphological similarities and differences of cases and is often used in research on the Russian language" (Arkadiev 2009, 64).

\section{Three-dimensional approach of Jakobson and Tronsky}

A nonconventional three-dimensional model of the Russian case paradigm has been presented by Roman Jakobson $\left(1985\right.$ a, b), ${ }^{8}$ see Fig. 1. Jakobson came up with a formally motivated case paradigm in which the place of each case is semantically determined. ${ }^{9}$ Interestingly enough, Jakobson took in consideration both completely homonymous forms and partially coinciding case inflections he referred to as "primety" 'marks'.

In a similar vein, Joseph Tronsky put forward a three-dimensional model of the Proto-Indo-European case system (Fig. 2) in which the oppositions between the elements

7 Arkadiev supplemented the traditional system with "partitive" and "locative" cases, which correspond to the second genitive and second prepositional in the Jakobson's scheme (see below, section 2).

8 Якобсон Р.О. К общему учению о падеже, в: Якобсон Р.О. Избранные работы. М., 1985, 133-175 (came out first in 1936 ("Beitrag zur allgemeinen Kasuslehre: Gesamtbedeutungen der russischen Kasus"); Якобсон Р.О. Морфологические наблюдения над славянским склонением, в: Якобсон Р.О. Избранные работы. М., 1985, 176-197 (first in 1958).

9 A detailed analysis of Jakobson's ideas is given in McCreight, Chvany 1991. 


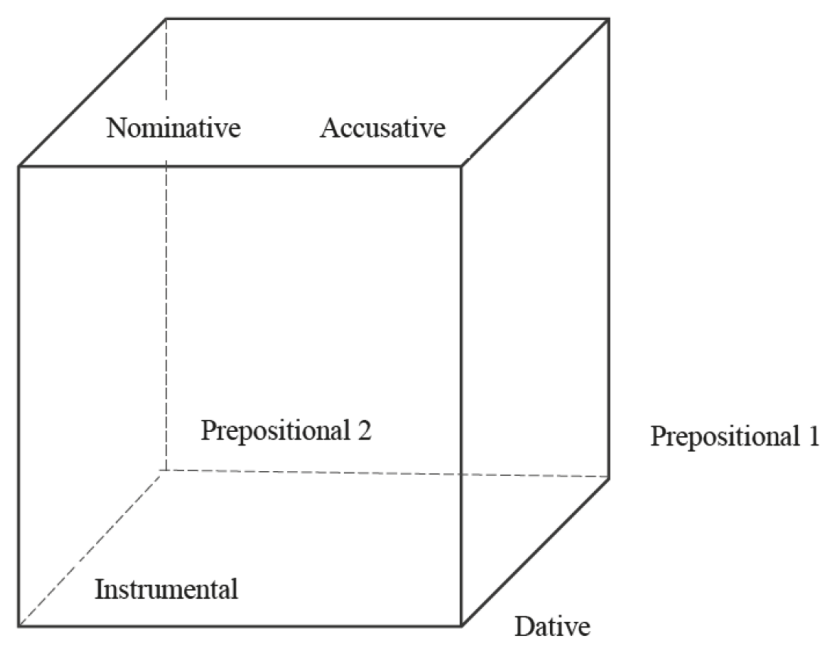

Fig. 1. Jakobson's three-dimensional model of the Russian case system

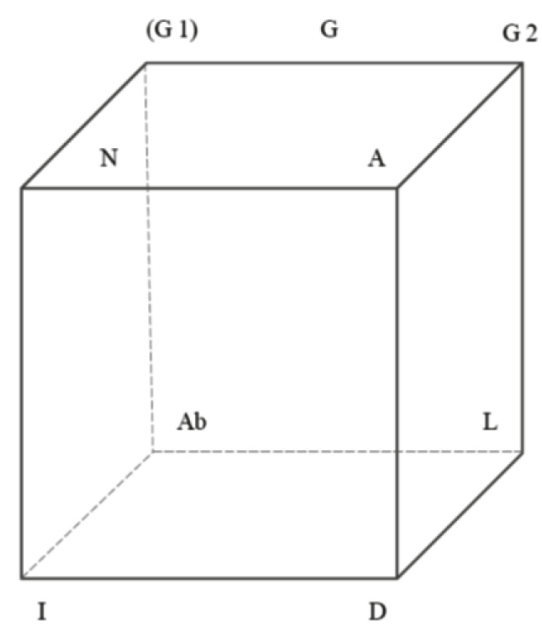

Fig. 2. Tronsky's three-dimensional model of the Proto-Indo-European case system

were based on the semantic roles performed by the cases in the syntagm (Tronsky 2001, 467). ${ }^{10}$

It is worth stressing that Jakobson and Tronsky have gone beyond the linear model of the case paradigm and convincingly argued that multidimensional schemes could better display the oppositions between cases. Jakobson's oppositions singled out for the Russian case system were based on morphemic and submorphemic neutralizations of neighboring elements. As regards Tronsky's concept, he also argued that neutralization could be one of

10 Тронский И.М. Историческая грамматика татинского языка. Общеиндоевропейское языковое состояние (вопросы реконструкиии). М., Индрик, ${ }^{2} 2001$. 
the reasons for the case syncretism, which eventually brought about the reduction of the case system in the Indo-European languages.

The semantic invariants for "neighboring" cases suggested by Jakobson and Tronsky are different (in Jakobson's system - "direction, volume, peripherality", in the Tronsky's "exocentricity, objectness, complicity"). Such discrepancies seem to result from some terminological issues rather than the essential incompliance between the two scholars. ${ }^{11}$

Although highly innovative, the cubic model of the Russian and Proto-Indo-European case systems suggested by Jakobson and Tronsky can hardly be considered universal. Jakobson's cube rests on the Russian eight-case system (with the addition of the second genitive and second prepositional). When trying to adjust the Proto-Indo-European (also eight-case) system to the cubic model, Tronsky $(2001,468)$ was forced not only to exclude the vocative, which really has a special status, ${ }^{12}$ but also to place the genitive at two points at once (i. e. Genitivus subiectivus and Genitivus obiectivus referred to as G1 and G2), which, given only one form of the genitive, at least in the noun system, looks like an attempt to fill the gap. ${ }^{13}$ Obviously, such a three-dimensional model can hardly be applied to other case systems since any deviation from the "eightfoldness" would either destroy this model or require more and more speculation. What is much more considerable, the pioneering breakthrough beyond linearity made by Jakobson and Tronsky does not consist in the "cubicity" of a paradigm but in highlighting the oppositional nature of paradigmatic relations.

Although put forward in the middle of the last century, Jakobson's ideas are still being discussed in literature. ${ }^{14}$ There are two approaches to the interpretation of his concept morphological and morphosyntactic ones. The morphological approach underlines the semantic and functional autonomy of syncretic forms, which completely rules out the possibility of cross-linguistic generalizations. The morphosyntactic approach, which was put forward by Jakobson, on the contrary, starts from the idea that the syncretism of cases is motivated by their common meaning and functions, and therefore, makes it possible to predict which cases can merge and which cannot, and trace this on various linguistic material (Baerman 2008, 221-222).

We will try to show that the morphosyntactic approach based on the ideas of Roman Jakobson and elaborated in the work of Konstantin Pozdniakov (Pozdniakov 2003;

11 The semantic invariants of cases suggested by Jakobson have come in for criticism, but his general idea has been highly estimated by scholars. See, for example, Pertsov 2001, 26 (Перцов Н. В. Инварианты в русском словоизменении. М., Языки русской культуры, 2001): “The specific description of Russian case meanings suggested by the author should be recognized as a failure, but the general concept seems correct and promising, and it is regrettable that attempts to develop a general theoretical idea of Jakobson were not as numerous as it deserves"; Ivanov 1985, 22 (Иванов Вяч. Вс. Лингвистический путь Романа Якобсона, в: Якобсон Р. О. Избранные работы. М., 1985, 5-29): "Unfortunately ... this line of Jakobson's work remained almost not continued, except for some enthusiastic remarks of our middle-generation linguists", and Pozdniakov 2003, 25: "After the publication of this observation, the middle generation of linguists has become older, but no one systemic study in this area has appeared". It is worth noting that Pozdnyakov's work, without a doubt, is such a systemic contribution to this research area.

12 See below our considerations on the status of the vocative.

13 The question of how many cases Latin and Russian have is not that easy, see, e. g., Comrie 1991, 42; $48-49$.

14 See Schooneveld 1986; McCreight, Chvany 1991; Pertsov 2001; Baerman 2008, inter alia. First versions of Jakobson's papers on Russian declension came out in 1936 and 1958. 
2009) $)^{15}$ is relevant for the Latin case system. Pozdniakov considers the neutralization process or - in other words - morphemic syncretism as an important, though not the only means to mark the oppositional relations between the signs. Based on this, the contextual neutralization of the opposition between two elements operates as a marker of belonging to one dimension. In contrast, the differences between these elements can show up in other contexts - paradigmatic or syntagmatic.

\section{Syncretism as a result of morphemic neutralizations in the Latin case system}

Syncretism of the Latin case inflections is a broadly known phenomenon, which has been analyzed in the context of related phenomena witin other inflectional case systems. ${ }^{16}$ It is worth stressing that "functional syncretism should be kept apart from morphological syncretism. The latter has its immediate cause in phonetic erosion; its result is the phonological identity of one or more morphemes" (Luraghi 1987, 356). In contrast, functional syncretism we deal with is understood as the merging of different morphemes based on the previous functional overlap and may be of semantic and syntactic origin (Luraghi 1987, 355-357). Sometimes the phonetic and semantic reasons operate hand by hand, which came about with the ablative, instrumental, and locative eventually merged in Latin: "This example from Latin is useful as it shows that phonetic processes $\langle\ldots\rangle$ do not represent the only driving force of case syncretism. All three source cases have left their traces in both the singular and plural paradigms at least in some of the attested Latin declensions, so phonetic processes alone could not yet result in the simple syncretism of these three cases. Hence, the final outcome is a result of a complex interplay of several mechanisms; in particular, the three source cases must be considered semantically (functionally) close enough to each other, which in turn has licensed the form of one of them to take over the functions of the other(s)" (Barðdal, Kulikov 2008, 474).

Despite the vivid interest of linguists in this topical issue, the exhaustive analysis of the paradigmatic structure based on the oppositions and neutralizations of the Latin cases has not yet been carried out.

First, we will try to analyze nominal and adjectival paradigms of all declensions (apart from the personal pronouns' paradigm, which will be considered in the special section) and present a complete inventory of morphemic neutralizations in Latin.

Based on the syncretism of the case forms, the following neutralizations can be distinguished: ${ }^{17}$

15 Поздняков К.И. Микроморфология или морфология парадигмы? Язык и речевая деятельность 2003, 5, 22-58; О природе и функциях внеморфемных знаков. Вопросы языкознания 2009, 6, $35-64$.

16 See Comrie 1991; Coleman 1991; Gvozdanovic 1991; Plank 1991; Barðdal, Kulikov 2008, and especially Luraghi 1987; 1991; 2001.

${ }^{17}$ It is worth stressing that only neutralizations of the elements within a single paradigm will be considered as syncretism while the similar forms from different paradigms (e. g., the forms in Gen. Sg. and Nom. Pl. of the first declension, like amicae) will be treated as homonymous rather than syncretic ones, which are beyond the scope of this paper. 
Nominative - accusative: 1) neuter nouns and adjectives in the singular and plural (e. g., bellum, corpus, cornu (N., Acc. Sg.), bella, corpora, cornua (N., Acc Pl.), 2) nouns and adjectives of the $3^{\text {rd }}, 4^{\text {th }}, 5^{\text {th }}$ declensions in the plural (e. g., leges, fluctus, $\operatorname{res}(\mathrm{N}$., Acc $\mathrm{Pl}$.).

Dative - ablative: 1) nouns and adjectives in the plural (e. g., legibus duris (D., Abl. Pl.), 2) nouns and adjectives of the $2^{\text {nd }}$ declension in the singular (e. g., animo (D., Abl. Sg.), 3) nouns and adjectives of the $3^{\text {rd }}$ declension with $-i$-stem (e. g., animali (D., Abl. Sg.), nouns of the $4^{\text {th }}$ declension in the singular (e. g., cornu (D., Abl. Sg.).

Nominative - genitive: nouns and adjectives of the $3^{\text {rd }}$ declension with $-i$-stem (e. g., hostis fortis (N., G. Sg.)).

Genitive - dative: nouns and adjectives of the $1^{\text {st }}$ and nouns of the $5^{\text {th }}$ declension in the singular (e. g., filiae amatae, diei (G., D. Sg.)).

Dative - accusative: neuter nouns of the $4^{\text {th }}$ declension in the singular (e. g., cornu (D., Acc. Sg.)).

To sum up, the nominative has syncretic forms with the accusative and genitive, the accusative - with the nominative and dative, the genitive - with the nominative and dative, the dative - with the accusative, genitive and ablative, and the ablative - with the dative.

\section{Paradigmatic structure of the core Latin cases}

In this section, the five core cases, ${ }^{18}$ i. e., nominative, accusative, genitive, dative, and ablative, will be considered. The next two sections will concern the "marginal" cases - the vocative and locative.

According to the well-known principle "there is no opposition without neutralization", ${ }^{19}$ we argue that the syncretism of cases is a manifestation of the oppositional relations between them. With this presumption in mind, we will have only one paradigmatic structure of the case oppositions (see Fig. 3), which will be based on the formal language data - the syncretic forms, rather than on

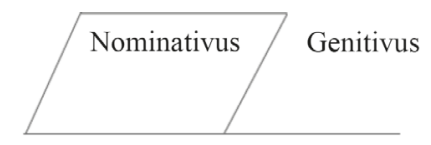

Accusativus Dativus Ablativus

Fig. 3. Paradigmatic structure of the core Latin cases the speculative semantic generalizations. It is to be stressed that in our scheme, syncretism of "non-adjacent" elements, e. g., accusative and ablative, is possible only on the condition that there is syncretism between the dative and ablative, that is, without the dative / ablative syncretism, the accusative / ablative syncretism is impossible either.

Since neutralization is nothing but a systemic process, one will find some correlations between the similar semantic and syntactic functions of the cases, on the one hand, and their neutralization, on the other. In what follows, we will show the correlations between the "paradigmatic vicinity" of the cases and the similarity of their functions and semantics. ${ }^{20}$

18 "Core" in terms of Comrie 1991, 48.

19 This principle was postulated in phonology, where the structure of paradigmatic oppositional relations was developed much better than in morphology.

${ }^{20}$ Surprisingly, it was Rasmus Rask who supposed first that semantic and functional affinities between cases (or presumably between the terms of any other category as well) are conducive to homonymy (Plank 1991, 190), but seemingly, Rask did not distinguish between homonymy and syncretism. 


\section{Functional and semantic similarity of the syncretic cases}

Let's start with syncretism of the nominative and accusative, as "principal" (or "direct") in comparison with the rest - indirect - cases. Thus, the accusative can take over the primary syntactic function of the nominative - to express the subject of an action or a state - in the construction Accusativus cum Infinitivo, in the function Accusativus exclamationis and constructions with impersonal verbs expressing repentance (poenitet), annoyance (piget), shame (pudet), and disgust (taedet) :

(1) Cassius semet eo brevi venturum pollicetur. (Sall. Cat. 44. 2)

(2) Ad illum modum sublitum os esse mi hodie! (Plaut. Capt. 783) ${ }^{21}$

(3) Quam me pudet nequitiae tuae, cuius te ipsum non pudet. (Cic. Phil. 2. 30. 76)

There is a functional similarity between the dative and ablative: the arguments marked with these cases may perform a semantic role of the agent in the passive constructions, which is traditionally called Ablativus auctoris (4) and Dativus auctoris (5-6):

(4) Idem hoc fit a principibus Hispaniae. (Caes. BGall. 1. 74, 5)

(5) Faciendum id nobis, quod parentes imperant. (Plaut. Stich. 54)

(6) Mihi captum consilium iam diu est. (Cic. Fam. 5. 19.2)

The semantic affinity of the nominative and genitive is not so obvious at first glance. However, functional similarity between them can also be found. ${ }^{22}$ Thus, Genitivus subiectivus, in fact, is a nominalization of a predicate whose subject changes its marking from nominative to genitive:

\section{(7) hostes metuunt > metus hostium; Caesar advenit > adventus Caesaris}

Besides, the genitive functions as a subject of the verbs interest and refert 'be important':

(8) Rei publicae interest mulieres dotes saluas habere, propter quas nubere possunt (Iust. Dig. 23. 3. 2.1)

The same holds for Genetivus characteristicus:

(9) Cuiusvis hominis est errare. (Cic. Off. 1. 122)

${ }^{21}$ Such cases can be interpreted as exclamative Accusativus cum Infinitivo (Pinkster 2015, 366).

22 In fact, the formal and functional similarity between the nominative and genitive is proved historically, because the affix ${ }^{*}$-os was common for the genitive and nominative of the active nouns in Proto-Indo-European (Gamkrelidze, Ivanov 1984, 270 (Гамкрелидзе Т. В., Иванов Вяч. Вс. Индоевропейский язык и индоевропейцы. Т.1. Тбилиси, Изд-во Тбилисского университета, 1984)). Sihler also points out the common inflection ${ }^{*}-s$ in Nom. Sg. and Gen. Sg. of masculine / feminine nouns (Sihler 1995, 250). A detailed survey of current views on the ergative / active stages of PIE language, see in Willi 2018, 504-544, with particular focus on coinciding endings for the non-neuter nominatives and genitives (p. 506), and in Kazansky 2019, 144. 
As regards the genitive and dative, both cases can express possession, resp. Genetivus possessivus and Dativus possessivus:

(10) Hic versus Plauti non est. (Cic. Fam. 9. 15)

(11) In hac insula est fons aquae dulcis cui nomen Arethusa est. (Cic. Verr. 4. 118)

Finally, the dative and accusative also have something in common when expressing the idea of "direction". ${ }^{23}$ It is known that the primary syntactic function of the dative is an indirect object in the constructions with bivalent and trivalent verbs:

(12) Venus nupsit Vulcano. (Cic. Nat. D. 3, 59)

(13) Diva solo fixos oculos aversa tenebat. (Verg. Aen. 1. 651)

However, the accusative can also indicate the direction, either without a preposition (Accusativus directionis), or more often, with a preposition:

(14) Balbus recta a porta domum meam venit. (Cic. Fam. 9. 19)

(15) Hannibal in hiberna Capuam concessit. (Liv. 23. 18)

In addition, both cases may express a purpose: hardly anyone would question the common purpose semantics of auxilio (Dativus finalis) in (16) and the supine irrisum in (17) which is in fact the "accusative form of abstract verbal noun of the fourth declension, ending in -um" (Pinkster 2015, 64):

(16) Pausanias venit Atticis auxilio. (Nep. 8, 3, 1)

(17) ... nunc venis etiam ultro irrisum dominum (Plaut. Am. 587).

All these examples leave no doubt that all the formal oppositions and neutralizations under consideration have functional and semantic correlations. Hence, the syncretism of cases is not accidental, which is displayed in Fig. 3 (above).

Thus, two crucial questions have got their answers - what the reason for the case syncretism is, and what the paradigm of cases looks like. As we have already seen, the most vulnerable part of paradigmatic constructions offered by Jakobson and Tronsky was an attempt to single out a semantic invariant for each case. Nevertheless, if such invariants are just an auxiliary tool of analysis based on the formal linguistic material, they seem much more motivated, although specific for the particular language rather than reflecting a kind of logical matrix.

In Latin, the opposition of the nominative and genitive, on the one hand, and the accusative, dative, and ablative, on the other, can be described as the semantic opposition of object cases (Acc., Dat., Abl.) vs. non-object cases (Nom., Gen.). ${ }^{24}$ What is more, the

23 On the dative of direction in Proto-Indo-European, see in detail Kazansky 1989, 118 (Казанский Н.Н. К реконструкции категории падежа в праиндоевропейском, в: А. В. Десницкая (ред.) Актуальные вопросы сравнительного языкознания. Л., Наука, 115-130).

${ }^{24}$ One can see a kind of contradiction of this statement with the function Genitivus obiectivus. However, it is not the case because this function is part of the nominal dependency and does not imply the in- 
accusative will convey direct "objectness", the dative - indirect one, and the ablative adverbial "objectness", while the nominative and genitive are not marked with the feature "objectness". In view of the involvement in the argument structure, the nominative and accusative are principal cases, as they are indispensable for a minimal predication, while without all the other cases such a predication is possible. Regarding the oblique cases, one can single out a common feature "possessiveness" for the genitive and dative, while the ablative will be marked by the feature "circumstanceness", i. e., less degree of involvement in the argument structure. All in all, the set of differential paradigmatic features of the five core cases looks like this:

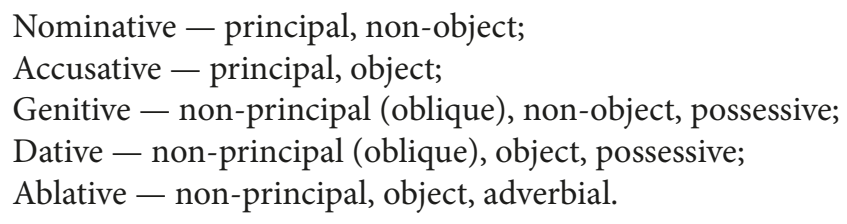

\section{Marginal cases within the general paradigmatic structure}

The fundamental problem of the paradigmatic models we had observed before is their inflexibility and inability to respond to dynamic changes languages inevitably subject to. The "eight-case cube" can be easily destroyed if the number of cases is increased or decreased. On the contrary, the paradigmatic system we suggest is relatively easy to adapt to the dynamic changes related to the "marginal" cases - Vocativus and Locativus whose traces are observable along the history of Latin. Moreover, our method makes it possible to integrate into the paradigm even Casus Instrumentalis, which is absent from Latin since it merged with the ablative as early as at the Proto-Italian stage.

\subsection{Vocative}

The vocative is a particular case often taken out of the case system (as Tronsky does in his work). Helen Vairel (1981) also takes this case out of the paradigm because of its obvious relevance to the category of the person rather than the case. If one follows the generally accepted definition of the case: "case is a system of marking dependent nouns for the type of relationship they bear to their heads" (Blake 2001, 1), it is clear that the vocative does not fit in with it, as it does not depend on any element of a syntagma and, accordingly, has no syntactic/semantic relations with other constituents. The ancient grammarians probably did understand this since it is not until Dionysius Thrax (170 - 90 B. C.) that the vocative was identified as a case and included in the case system (Blake 2001, 19).

The vocative has a dual nature. It is associated deictically and pragmatically with the addressee and, therefore, is directly related to the $2^{\text {nd }}$ person pronouns rather than to the other cases. At the same time, morphologically, the vocative has syncretic forms with the nominative in all declensions except for the masculine singular nouns and adjectives of the $2^{\text {nd }}$ declension and several Greek nouns. Thus, we must admit both the vocative's opposition to all other cases and its morphological closeness to the nominative.

volvement of the genitive in the verb argument structure, for which the term "objectness" is relevant. About the genitive as marking nominal dependency, see Luraghi 1987, 362-363. 
Such a "provocative" character of the vocative is highlighted by M. Daniel and E. Spencer in their typological paper: "The fact that the vocative can form part of the case paradigm without realizing any recognized grammatical or other case-like relation means that it poses an interesting challenge to our conceptions of what a case is" (Daniel, Spencer 2008, 234).

Since we have already postulated the obligatory dependence of the case paradigm on the morphemic syncretism, which is clearly observed in the vocative case, we should integrate it into the scheme we have proposed. Such integration, however, will not challenge our methodology, which is flexible and open to any dynamic changes: the contradiction between the syncretism of the vocative and nominative, which creates the oppositional relations between them, and the lack of the "case-like relations" between the vocative and the other cases, will be overcome by opening a "new dimension", see Fig. 4 .

The semantic invariant for the vocative, therefore, is its "deicticity". Being syntactically unmarked, the vocative tends to be a pure stem without inflection, as its counterpart - the nominative - often does. Its paradigmatic position is characterized by minimal involvement in the opposition system, making it less stable than other cases and, accordingly, the right candidate for reduction. From this viewpoint, the next candidate for such a reduction is ablative, which is clearly documented by the Latin case system's history.

\subsection{Locative}

It should be mentioned that there were two more cases in the Proto-Indo-European language - the instrumental and the locative. Unlike the instrumental, which merged with the ablative back in the Proto-Italian (Hofmann, Szantyr 1972, 21-22), the locative had its own long history. Although the locative was ruled out from the paradigm of Latin cases by Roman grammarians, since the locative functions in classical Latin basically were performed by the ablative, rudimentary this case continued to exist and was actively used in some common nouns (e. g., domi, humi, ruri (rure), militiae) and in the names of cities and islands (e. g., Romae, Corinthi, Delphis, Cypri). As is clear from the examples, it has a genitive-like ending in the $1^{\text {st }}$ and $2^{\text {nd }}$ declensions, and ablative-like ending in the $3^{\text {rd }}$ declension and in the plural nouns of all declensions:

(18) Ut Romae consules, sic Carthagine quotannis annui bini reges creabantur. (Nep. 21. 7. 4)

According to Sihler, "such case syncretisms are commonplace, but the merging of the ablative and locative is puzzling: the notions 'at, in, on' are functionally remote from 'away'" (Sihler 1995, 253). This merger could be based on the similarity of the inflections of Abl. Sg. and Loc. Sg. -e, which, however, had a different origin (Sihler 1995, 285), but for Sihler, the merging of the dative and locative would be more understandable (Sihler 1995, 253). As for the similarity of the genitive and locative, it is the result of the historical development and syncretism of two different inflections: $-i$ (G. Sg.) and -ei (Loc.Sg.) (Sihler 1995, 260). 
Vocativus

Nominativus Genitivus Locativus

Accusativus Dativus Ablativus

Fig. 5. Paradigmatic structure of the Latin cases (including the vocative and locative)
Our approach will solve the mystery of both the ablative/locative conflation and the genitive/locative merging. It will also explain the marginal and disappearing status of the locative in Latin (see Fig. 5): the geometrically predictable paradigmatic position of the locative between the genitive and ablative is motivated by its syncretism with these cases.

The weakest - compared to other cases - status of the locative is explained by the fact that its syncretism is complete. The locative has no forms that do not coincide with either

the genitive or the ablative, while all other cases (including the vocative) do have such forms. The lack of its own inflections eventually led to its early "squeezing" out of the paradigm.

In Latin grammars, the locative can be included in the paradigm or excluded from it, but our scheme is compatible with any variant due to its dynamic potential. The feature "circumstanceness" which had been singled out earlier in the ablative correlates well with the paradigmatic position of the locative, as well as its "non-object" character. If one allows for the locative in the paradigm, its paradigmatic invariant should be described as follows: non-principal, non-object, adverbial. ${ }^{25}$

The system of oppositions we suggest would have allowed us to reconstruct the position of Instrumentalis had it been preserved in Latin: it would be located on the same line with the accusative, dative, and ablative. Neutralization of the opposition between the ablative and instrumental must have taken place very early. This early neutralization and merger of the two cases could probably be due to the minimal involvement of the instrumental in the paradigmatic oppositions (in fact, only with the ablative). The same holds for the scenario of reducing the ablative itself, although much later, at the final stage of the Latin language (Calboli 1983, 47).

\section{Pronominal cases in Latin}

The syncretism of case inflections in the personal pronouns' system differs significantly from what we have observed in the noun system. Besides the most common neutralizations which are found throughout all Latin declensions in the plural (nos - Nom/ Acc 1pers. Pl., vos - Nom/Acc 2 pers. Pl., nobis - Dat/Abl 1 pers.Pl., vobis - Dat/Abl 2 pers.Pl.) there is only one neutralization in the singular: me - Acc/Abl 1 pers. Sg., te Acc/Abl 2 pers. Sg. (Table 2).

Table 2 highlights three issues we face in describing paradigmatic oppositions within the pronominal case system: first, the differences in the syncretism of the nominal and pronominal cases will inevitably bring about some changes in the pronominal paradigm as compared to the nominal one; second, the neutralizations we observe in Table 2 are not enough to "glue" the paradigm, which is their functional role; third, Genitive 1 and Genitive 2 do not form neutralizations with any other cases, while the difference between the two genitives themselves is neutralized in the singular and is realized in the plural.

25 A similar observation that "ablative, locative and instrumental were the cases of circumstantial rather than core relations in Indo-European" is found in Luraghi 2002, 39-40 and Serbat 1989, 281. 
Table 2. Declension of the personal pronouns with the emphasis on the case neutralizations

\begin{tabular}{|c|c|c|c|c|}
\hline & $1 \mathrm{Sg}$. & $2 \mathrm{Sg}$. & $1 \mathrm{Pl}$. & $2 \mathrm{Pl}$. \\
\hline Nominative & ego & $t \bar{u}$ & $n \bar{o} s$ & $v \bar{o} s$ \\
\hline Genitive 1 & $m e \bar{\imath}$ & $t u \bar{\imath}$ & nostrī & vestrī \\
\hline Genitive 2 & - & - & nostrum & vestrum \\
\hline Dative & mihì & $t i b \bar{\imath}$ & nōbīs & $v \bar{o} b \bar{i} s$ \\
\hline Accusative & mē & tē & $n \bar{o} s$ & $v \bar{o} s$ \\
\hline Abative & mē & tē & $n \bar{o} b \bar{i} s$ & $v \bar{o} b \bar{i} s$ \\
\hline
\end{tabular}

In what follows, we will try to offer a solution to all these issues.

\subsection{The role of possessive pronouns in shaping the pronominal paradigm}

Whereas in the nominal paradigm, syncretic forms are in complementary distribution to each other throughout all declensions, the personal pronouns seem to lack such variability. This, however, is not entirely true. Historically, possessive pronouns turned out to be in complementary distribution to personal pronouns (Tronsky 2001, 197). Actually, the possessive pronouns meus, tuus, noster and vester follow the standard adjective declension and, therefore, are part of the nominal case paradigm. At the same time, they are closely related to the paradigm of personal pronouns since they indicate the possessor's grammatical person. ${ }^{26}$ Consequently, the category of person is relevant for both personal and possessive pronouns. Therefore, while analyzing syncretism of the personal pronouns, we can also take into consideration the syncretism of the possessive pronouns, which - in addition to the oppositions Nom/Acc and Dat/Abl - will give us the opposition Gen/Dat: meae - Gen/Dat 1 pers. Sg., f;

tuae - Gen/Dat 2 pers. Sg., f;

nostrae - Gen/Dat 1 pers. Pl., f;

vestrae - Gen/Dat 2 pers. Pl., f. (Table 3 ).

Table 3. Declension of the possessive pronouns meus and noster ${ }^{27}$

\begin{tabular}{|c|c|c|c|c|c|c|}
\hline & \multicolumn{6}{|c|}{ Possessor in the singular } \\
\hline & \multicolumn{3}{|c|}{ Possessee in the singular } & \multicolumn{3}{|c|}{ Possessee in the plural } \\
\hline Gender & \multirow[t]{2}{*}{$\mathrm{m}$} & \multirow[t]{2}{*}{$\mathrm{f}$} & \multirow[t]{2}{*}{$\mathrm{n}$} & \multirow[t]{2}{*}{$\mathrm{m}$} & \multirow[t]{2}{*}{$\mathrm{f}$} & \multirow[t]{2}{*}{$n$} \\
\hline Case & & & & & & \\
\hline Nom. & meus & mea & meum & $m e \bar{\imath}$ & meae & mea \\
\hline
\end{tabular}

${ }^{26}$ Historically, possessive pronouns are ordinary adjectives formed from the stem of the personal pronouns by adding thematical inflection -o-/-eH2- or the contrastive suffix -tero-/tereH2- (Sihler 1995, 382). noster.

27 The declension of tuus and vester is not provided in Table 2 since it does not differ from meus and 


\begin{tabular}{|c|c|c|c|c|c|c|}
\hline \multirow{4}{*}{$\begin{array}{l}\text { Dat. } \\
\text { Acc. }\end{array}$} & \multicolumn{6}{|c|}{ Possessor in the singular } \\
\hline & \multicolumn{3}{|c|}{ Possessee in the singular } & \multirow{2}{*}{\multicolumn{3}{|c|}{$\begin{array}{c}\text { Possessee in the plural } \\
\text { meīs }\end{array}$}} \\
\hline & mēō & meae & mēō & & & \\
\hline & meum & meam & meum & meōs & meās & mea \\
\hline Abl. & $m e \bar{o}$ & $m e \bar{a}$ & meō & meīs & & \\
\hline
\end{tabular}

\begin{tabular}{|l|l|l|l|l|l|l|}
\hline & \multicolumn{3}{|c|}{ Possessee in the singular } & \multicolumn{3}{c|}{ Possessee in the plural } \\
\hline & $\mathrm{m}$ & $\mathrm{f}$ & $\mathrm{n}$ & $\mathrm{m}$ & $\mathrm{f}$ & $\mathrm{n}$ \\
\hline Nom. & noster & nostra & nostrum & nostrī & nostrae & nostra \\
\hline Gen. & nostrī & nostrae & nostrī & nost(rō)rum & nostrārum & nost $($ rō)rum \\
\hline Dat. & nostrō & nostrae & nostrō & \multicolumn{4}{c|}{ nostrīs } \\
\hline Acc. & nostrum & nostram & nostrum & nostrōs & nostrās & nostra \\
\hline Abl. & nostrō & nostrā & nostrō & \multicolumn{4}{|c|}{ nostrīs } \\
\hline
\end{tabular}

It is clear that both in the nominal and in the pronominal paradigm, all the cases are bound by morphemic syncretism. However, in the pronominal paradigm, this connection seems less rigidly structured than in the nominal one: oppositional relations do not connect the genitive with the nominative, the accusative - with the dative, and the ablative fundamentally changes its paradigmatic position by shifting towards the accusative. The structure looks much less coherent and compact than in the case of the noun paradigm (Fig. 6):

Nominativus Accusativus Ablativus Dativus Genitivus 1 Genitivus 2

Fig. 6. Paradigmatic structure of the pronominal cases in Latin

Although the pronominal paradigm looks simplified and monodimensional compared to the nominal one, it is still based on the crucial methodological principle: the cases linked to each other have syncretic forms based on the partial overlapping of their semantic and syntactic functions.

\subsection{The special status of the nominative within the pronominal paradigm}

The pronominal paradigm drawn up above (Fig. 6) does not consider a fundamentally different (compared to the nominal case system) relationship of the nominative to the rest of the cases based on its special pragmatic status. Indeed, in the nominal paradigm, the nominative is a full-fledged member of the syntactic structure, with its role of the subject (first argument), which is implicitly or explicitly present in the vast majority of Latin clauses. 
On the contrary, personal pronouns in the nominative have a completely different semantic-pragmatic status: the forms ego, $t u$, nos, vos are not necessary to convey a pronominal subject, since this function belongs to the personal verb inflection, which is characteristic of the pro-drop languages Latin belongs to.

Personal pronouns in the nominative are not necessary participants of a minimal actant structure in Latin: the famous aphorism that ancient tradition attributes to Caesar Veni, vidi, vici (Sen. Suas. 2. 22) - does not require ego, as well as the proverb Dum docemus, discimus may perfectly do without nos. The use of the personal pronoun ego is possible in "Veni, vidi, vici", but it would function as a contrastive focus rather than as part of an unmarked affirmative sentence. It would mean "It's me, who came, saw and won" (sc. "me, not someone else"). This functional peculiarity is underlined by Sihler $(1995,370)$ : "the so-called nom. of a personal pronoun is not a subject case but rather an emphatic or topicalizing particle like Fr. moi 'as for me" (Sihler 1995, 370). ${ }^{28}$

Because of its pragmatic rather than syntactic function, the nominative does not fit in with the classical definition of case (Blake 2001, 1). What is more, the nominative turned out to challenge our pronominal paradigm (Fig. 6) as morphologically related to the accusative due to the case syncretism, but syntactically opposed to all other cases. The problem, again, is solved by opening a "new dimension" (Fig. 7):

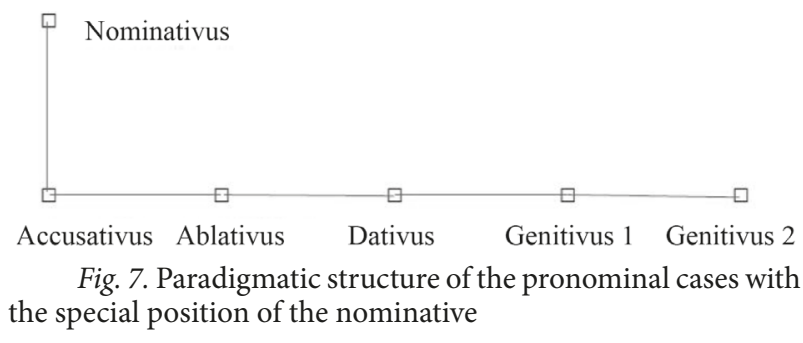

Figure 7 shows the syncretism Nom/Acc and the nominative's opposition to all other cases based on its pragmatic rather than syntactic nature.

It is worth mentioning that the replacement of the nominative by the accusative in the pronominal paradigm is historically determined. Latin has lost the old stems, which in the nominative plural differed from those in the oblique cases. Eventually, the accusative plural $n \bar{o} s$ and $v \bar{o} s$ started operating as the nominative (Tronsky 2001, 197). The secondary character of the nominative nōs and $v \bar{s} s$ was probably "fostered by the formal identity of nom. and acc. pl. in the nouns" (Sihler 1995, 381). In our opinion, the replacement could come about due to the similar syntactic functions of both cases in some constructions. ${ }^{29}$ As indicated in section 5 , the accusative used to take over the primary function of the nominative in Accusativus cum Infinitivo, Accusativus exclamationis, and in the constructions with the impersonal verbs expressing repentance (poenitet), annoyance (piget), shame (pudet), disgust (taedet) (see ex. 1-3 in section 5).

${ }^{28}$ Cf. ego veni in Cicero's letter to Attic in which ego is in contrast with frater: quae res se sic habet: $u$ t veni in Arpinas, cum ad me frater venisset, in primis nobis sermo isque multus de te fuit; ex quo ego veni ad ea quae fueramus ego et tu inter nos de sorore in Tusculano locuti (Cic. Att. 5. 1.3).

29 The repertoire of such constructions has built up over time. On the expansion of the accusative in Late Latin, see Cennamo 2011, 170-171; Rovai 2012, 98-100. 
As regards the syncretism of the accusative and ablative, it could come about due to the common semantics of direction, albeit with the opposite vectors, which is clear from the example:

(19) Quasique anulum hunc ancillula tua abs te detulerit ad me. (Plaut. Mil. 912)

\subsection{Pronominal cases and peculiarities of the genitive}

A considerable difference between the nominal and pronominal paradigms is also observed in the genitive.

In a number of languages, personal pronouns' genitive can convey possessiveness, either alongside or instead of possessive pronouns. In Ancient Greek, for example, the

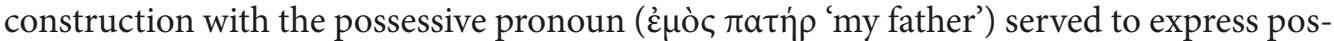
session along with the personal pronoun in the genitive ( $\pi \alpha \tau \eta \dot{\rho} \rho$ ov 'my father'). In Modern Greek, the possessive pronoun has been entirely replaced by the genitive (o $\pi \alpha \tau$ ' $\rho a \varsigma$ nov 'my father').

In some languages, the ways of expressing possessiveness depend on the person: in Russian, possessiveness in the $1^{\text {st }}$ and $2^{\text {nd }}$ persons is expressed by the possessive pronouns (“моя/твоя книга" 'my/your book'), while in the $3^{\text {rd }}$ person - by the suppletive forms of the personal pronouns in the genitive (“его/еe/их книга" 'his/her/their book'). Notably, in Russian, the forms of the $3^{\text {rd }}$ person pronouns are syncretic. We will refer to this kind of syncretism as "transparadigmatic", since the overlapping forms occur in the paradigms of both personal and possessive pronouns, cf.: “увидел ее” 'I saw her' (Acc. Sg. f., personal pronoun) / "ее книга" 'her book' (Gen. Sg. f, possessive pronoun). ${ }^{30}$ This observation is extremely significant because the transparadigmatic syncretism of personal and possessive pronouns occurs in Latin, too: mei/tui/nostri/vestri (Gen. 1) are in origin Gen. Sg., and nostrum/ vestrum (Gen. 2) - Gen. Pl. of the possessive pronouns (Sihler 1995, 376377, 381; Baldi 1999, 339-340). ${ }^{31}$ It does not come as a surprise that the only neutralization of the genitive (i. e., neutralization Gen./Dat. f., such as nostrae ${ }^{32}$ ) is observed in the paradigm of possessive pronouns - in the paradigm of personal pronouns, the genitive forms may seem too "alien" to participate in neutralization.

Concerning the distribution of the genitive's functions, Arnold et al. $(1997,163)$ says that the possessive pronouns seem preferable compared to the personals' genitives even in the prepositional phrases like meā gratiā instead of meī gratiō 'for my sake. ${ }^{33}$

Examples of the genitive 2 used in the possessive function are very few and almost always occur with omnium, e. g., communis nostrum omnium patria (Cic. Fl. 2. 5): in our opinion, the personal nostrum might be preferred to the possessive nostra due to the emphatic omnium with the similar ending and for the sake of chiasm. By contrast, in ex. (20)

${ }^{30}$ Similar syncretism can be observed in English, as is clear from the examples 'I saw her' and 'her book'.

${ }^{31}$ In German, the lacking genitives of the $1^{\text {st }}$ and $2^{\text {nd }}$ person pronouns are replaced by the possessive meiner and deiner, too. We are indebted to Michael Pozdnev for reminding us of this parallel.

32 Interestingly, the same neutralization is found in Russian "нашей” 'our's' (Gen/Dat. f.).

33 E. g., hoc vide ut dormiunt pessuli pessumi nec mea gratia commovent se ocius (Plaut. Curc. 154). In the database PHI-5, the ratio meà gratiā : meì gratiō is 4:1. 
mei goes as Gen. obiectivus rather than Gen. possessivus, since it is mea (the possessive proper) that conveys possessiveness here:

(20) Patria o mei creatrix, patria o mea genetrix (Catull. 63. 50).

From the above observations, it is clear that the functions of the genitive in the paradigm of personal pronouns are distributed in three forms:

1) the prototypical possessive function which determined the neutralization of the genitive and dative in the noun paradigm (see Fig. 3) shifts to the paradigm of possessive pronouns;

2) the partitive function (Gen. 2) belongs to the form which is possessive in origin and - what is important - functionally and semantically related to the ablative, ${ }^{34}$

3) the object functions that have much in common with the accusative functions are expressed by another form of the genitive (Gen. 1), also borrowed from the paradigm of possessive pronouns.

Thus, the genitive in the pronominal paradigm takes three positions that correspond to the three different, though originally related forms. It allows us to display the paradigmatic structure of personal pronouns while respecting the principle we had claimed before: any opposition within the case paradigm must be motivated by the syncretism of the related case forms (Fig. 8):

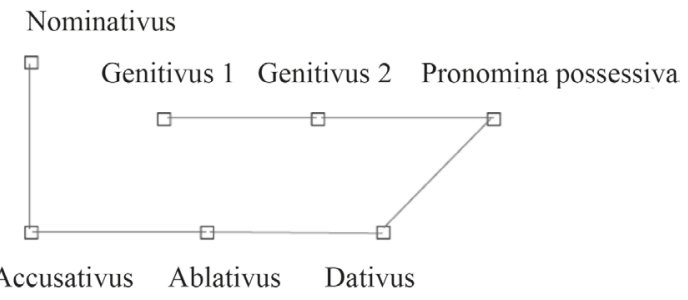

Fig. 8. Paradigmatic structure of the pronominal cases in view of peculiarities of the nominative and genitive

Figure 8 shows that the nominative is opposed to all other cases as "non-syntactic" or "emphatic" but syncretic with the accusative; the genitive is distributed over three different points on one line corresponding to the three forms which are possessive in origin.

It is essential that syncretism of the possessive pronouns in the dative and genitive holds together two independent paradigms related by kinship. ${ }^{35}$

This model's relevance is supported by sufficient evidence that "neighboring" cases with syncretic forms perform similar syntactic functions. Even cases that are not related by syncretism but located symmetrically on the rectangle's parallel lines also have partly overlapping semantic values. Let us look at the examples.

${ }^{34}$ It is not accidental that the partitive semantics in Latin can be conveyed not only by the genitive, but also by the ablative with the preposition e/ex, cf.: unus e nobis = unus nostrum 'one of us'. About the semantic affinity of the genitive and ablative, see Woodcock 1959, 28; Luraghi 1987, 362-363.

35 Personal and possessive pronouns are reciprocally related: whereas the possessives take the stems of the personal pronouns, the personals borrow some forms from the possessives (Sihler 1995, 376-377, 381-382). 
The similar semantics of Nom/Acc and Dat/Abl has already been exemplified in section 5(1-6).

The transparadigmatic syncretism of the genitive and dative, which holds together the pronominal paradigm, rests on the common semantics of possessiveness, cf. Dativus possessivus and Pronomen possessivum:

(21) Mihi est Menaechmo nomen. (Plaut. Men. 1068)

(22) Cylindrus ego sum: non nosti nomen meum? (Plaut. Men. 294)

The ablative and genitive 2 are also bound by the common semantic feature "ablativeness" which is syntactically conveyed by Ablativus separationis and Genitivus partitivus:

(23) Quisnam a nobis egreditur foras? (Ter. Haut. 561) $)^{36}$

(24) Quem enim nostrum ille moriens apud Mantineam Epaminondas non delectat? (Cic. Fam. 5. 12.5)

The genitive 1 with its syntactic function Genitivus obiectivus is semantically related to the accusative: both are marked by the common feature "(direct) objectness" ${ }^{37}$ Examples (25-26) show that the verb memini "to remember" can take complements both in the accusative and in the genitive: ${ }^{38}$

(25) Dic mihi, ecquid meministi tuom parentum nomina. (Plaut. Poen. 1062)

(26) Faciam, ut mei memineris, dum vitam vivas. (Plaut. Pers. 494)

It is worth stressing that the borrowed character of all genitive forms makes the pronominal paradigm significantly less coherent than the nominal one. There are no neutralizations between functionally similar accusative and genitive 1, as well as between the ablative and genitive 2; therefore, there are no oppositions between them in our model.

\section{Conclusions}

In this study, we tried to discover an internal mechanism that brings the elements of a paradigm together, and to present a new model of the nominal and pronominal case paradigms in Latin. We pursued the idea that a drastic role in structuring a case paradigm

36 It is worth mentioning that animate nouns and personal pronouns are always used with the preposition a/ab/abs in Ablativus separationis, see Sobolevsky 1998, 144 (Соболевский С.И. Грамматика латинского языка. СПб., Алетейя, 1998).

${ }^{37}$ Concerning direct and indirect objects, there is no consensus among scholars. Indeed, the verbs with the same meaning may have the second argument both in the accusative and in the dative / genitive without any semantic difference (Woodcock 1959, 42; Pinkster 2015, 1192), e. g., medeor tibi (Dat.) vs. sano te (Acc.): in both examples, the second argument performs the syntactic function of direct complement, although expressed in different cases.

${ }^{38}$ This genitive is traditionally called Genitivus memoriae. The semantic differences between the complements in Genitivus memoriae and the accusative are subtle. However, Pinkster suggests that the accusative is generally used with inanimate nouns while the genitive - with animate ones (Pinkster 2015, 118). Our examples (25) and (26) correspond to this assumption. 
belongs to morphemic syncretism, which is treated as a systemic phenomenon of morpheme neutralization rather than a result of the phonetic reduction.

Our particular focus was on the role of syncretism for gluing a paradigm and providing it with dynamic potential. We tried to highlight the importance and explanatory potential of the paradigmatic morphology as well as its objective character due to the fact that the paradigmatic analysis rests on the internal formal properties of language. In the case paradigm proposed in this study, the elements marked with the same endings necessarily take adjacent positions. There is a correlation between the similar forms and syntactic functions of the syncretic cases, which is supported by the examples from the Latin authors. Taking this as reference point, we established a formally motivated paradigmatic order of cases and singled out a set of semantic features that shape the case paradigm. What is more, the non-contradictory paradigmatic positions were found for both five core and two "marginal" cases - the vocative and locative.

The approach we have applied highlighted a fundamental discrepancy between the nominal and pronominal paradigms formed by partly different oppositions and syncretism. The crucial difference between pronominal and nominal cases appeared in the "non-syntactic" character of the pronominal nominative and borrowed nature of the originally possessive genitive forms. The main functions of the pronominal genitive turned out to be distributed among three different forms: the possessive function is given to the possessive pronouns, the partitive function - to the genitive 2 , and the object functions - to the genitive 1 . Thus, it can be argued that the pronominal paradigm is shaped by a kind of transparadigmatic syncretism, which determines its peculiarity compared to the nominal one.

Considering case syncretism in this way, we have drawn up the synchronic paradigmatic structure of the nominal and pronominal cases in Latin, grounded on a strictly formal analysis, which takes "paradigmatic" linguistics beyond purely logical impressionistic schemes.

\section{References}

Arkadiev P. M. Cases in the World Languages, in: E. V. Muravchenko, A.Ch. Piperski, O. Ju. Shemanaeva (eds). Linguistics for Everybody. Summer Linguistic Schools of 2007 and 2008. Moscow, 2009, 59-71. (In Russian)

Arnold T. K. et al. "Bradley's Arnold" Latin Prose Composition. New York, Aristide D. Caratzas, 1997.

Baldi Ph. The Foundations of Latin. Berlin - New York, Mouton de Gruyter, 1999.

Baerman M. Case Syncretism, in: A. L. Malchukov, A. Spencer (eds). The Oxford Handbook of Case. Oxford, Oxford University Press, 2008, 219-230.

Barðdal J., Kulikov L. Case in Decline, in: A. L. Malchukov, A. Spencer (eds). The Oxford Handbook of Case. Oxford, Oxford University Press, 2008, 470-478.

Barwick K. Rec. E. Sittig, Das Alter der Anordnung unserer Kasus und der Ursprung ihrer Bezeichnung als 'Fälle'. Stuttgart, Kohlhammer, 1931. Gnomon 1933, 9 (11), 587-594.

Blake B. J. Case. Cambridge, Cambridge University Press, ${ }^{2} 2001$.

Blake B. J. History of the Research on Case, in: A. L. Malchukov, A. Spencer (eds). The Oxford Handbook of Case. Oxford, Oxford University Press, 2008, 13-26.

Calboli G. The Development of Latin (Cases and Infinitive), in: H. Pinkster (ed.) Latin Linguistics and Linguistic Theory. Amsterdam, John Benjamins, 1983, 41-58.

Carvalho P. Le système des cas latins, in: H. Pinkster (ed.) Latin linguistics and linguistic theory. Amsterdam, John Benjamins, 1983, 59-71. 
Cennamo M. Impersonal Constructions and Accusative Subjects in Late Latin, in: A. Malchukov, A. Siewerska (eds). Impersonal Constructions: A Cross-Linguistic Perspective, Amsterdam, John Benjamins, 2011, 169-189.

Coleman R. The assessment of paradigm stability: Some Indo-European case studies, in: F. Plank (ed.) Paradigms: The Economy of Inflection. Berlin — New York, Mouton de Gruyter, 1991, 197-210.

Comrie B. Form and function in identifying cases, in: F. Plank (ed.) Paradigms: The Economy of Inflection. Berlin - New York, Mouton de Gruyter, 1991, 41-56.

McCreight K., Chvany C. V. Geometric representation of paradigms in a modular theory of grammar, in: F. Plank (ed.) Paradigms: The Economy of Inflection. Berlin - New York, Mouton de Gruyter, 1991, 91-112.

Daniel M., Spencer, A. The Vocative - An Outlier Case, in: A. L. Malchukov, A. Spencer (eds). The Oxford Handbook of Case. Oxford, Oxford University Press, 2008, 626-634.

Gamkrelidze T. V., Ivanov Vyach. Vs. Indoeuropean Language and People. Vol. 1. Tbilisi, Izdatel'stvo Tbilisskogo Universiteta, 1984. (In Russian)

Gvozdanovic J. Syncretism and the paradigmatic patterning of grammatical meaning, in: F. Plank (ed.) Paradigms: The Economy of Inflection. Berlin - New York, Mouton de Gruyter, 1991, 135-160.

Hofmann J. B., Szantyr A. Lateinische Syntax und Stilistik. Teil 2. Bd. 2. München, C. H. Beck Verlag, 1972.

Ivanov V'ach. Vs. The Linguistic Path of Roman Jakobson, in: Roman Jakobson. Selected works. Moscow, 1985, 5-29. (In Russian)

Jakobson R. O. To the General Case Study, in: Roman Jakobson. Selected works. Moscow, 1985a, 176-197. (In Russian)

Jakobson R. O. Morphological Observations on Slavic Declension, in: Roman Jakobson. Selected works. Moscow, 1985b, 176-197. (In Russian)

Kazansky N. N. On the Reconstruction of the PIE Category of Case, in: A. V. Desnitskaia (ed.) Current Issues of Comparative Linguistics. Leningrad, Nauka Publ., 1989, 115-130. (In Russian)

Kazansky N. N. Rec. Willi 2018. Voprosy Jazykoznanija 2019, 4, 137-154. (In Russian)

Kennedy B. H. The Shorter Latin Primer. Revised by J. Mountford. London, Longman, ${ }^{7} 1972$.

Luraghi S. Patterns of Case Syncretism in Indo-European Languages, in: A. G. Ramat, O. Carruba, G. Bernini (eds). Papers from the $7^{\text {th }}$ International Conference on Historical Linguistics. Amsterdam - Philadelphia: John Benjamins Publishing Company, 1987, 355-372.

Luraghi S. Paradigm size, possible syncretism, and the use of adpositions with cases in flective languages, in: F. Plank (ed.) Paradigms: The Economy of Inflection. Berlin - New York, Mouton de Gruyter, 1991, $57-74$.

Luraghi S. Syncretism and Classification of Semantic Roles. Sprachtypologie und Universalienforschung 2001, $54(1), 35-51$.

Pertsov N. V. Invariants in Russian Inflection. Moscow, Iazyki russkoi kul'tury Publ., 2001. (In Russian)

Plank F. Rasmus Rask's dilemma, in: F. Plank (ed.) Paradigms: The Economy of Inflection. Berlin - New York, Mouton de Gruyter, 1991, 161-196.

Pinkster H. Oxford Latin Syntax. Oxford, Oxford University Press, 2015.

Pozdniakov K. I. Micro-Morphology or Morphology of a Paradigm? Iazyk i rechevaia deiatel'nost' 2003, 5, 22-58. (In Russian)

Pozdniakov K.I. About Nature and Functions of Non-Morphemic Signs. Voprosy Iazykoznaniia 2009, 6, 35-64. (In Russian)

Rovai F. Between Feminine Singular and Neuter Plural: Re-analysis Patterns. Transactions of the Philological Society 2012, 110 (1), 94-121.

Royal W. A. Treatise on Latin Cases and Analysis. New York, Sheldon and Company; Wake Forest, North Carolina, J.S. Purifoy, 1860.

de Saussure F. Works on Linguistics, Moscow, Progress Publ., 1977. (In Russian)

Serbat G. Cas et fonctions. Paris, Presses Universitaires de France, 1981a.

Serbat G. Le système des cas est-il systèmatique? Revue des Etudes Latines 1981b, 59, 298-317.

Serbat G. Le syncrétisme des cas: Quelques réflexions, in: G. Calboli (ed.) Subordination and Other Topics in Latin. Proceedings of the Third Colloquium on Latin Linguistics, Bologna, 1-5 April 1985. Amsterdam Philadelphia, John Benjamins Publishing Company, 1989, 273-288.

Sihler A.L. New Comparative Grammar of Greek and Latin. New York, Oxford, Oxford University Press, 1995. 
van Schooneveld C. H. Jakobson's Case System and Syntax, in: R. D. Brecht, J. S. Levine (eds). Case in Slavic. Columbus, OH, Slavica Publishers, 1986, 373-85.

Sobolevsky S. I. Latin Grammar. St. Petersburg, Aleteia Publ., 1998. (In Russian)

Tronsky I. M. Historical Latin Grammar. Common Indoeuropean Language State. Moscow, Indrik Publ., ${ }^{2} 2001$. (In Russian)

Uhlig G. (ed.) Grammatici Graeci. Vol. 1. Leipzig, Teubner, 1883 (repr. 1965).

Vairel H. The Position of the Vocative in the Latin Case System. The American Journal of Philology 1981, 102 (4), 438-447.

Wheelock's Latin. s. a. Revised by R. A. LaFleur. $6^{\text {th }}$ ed. Harper Resource.

Willi A. Origins of the Greek verb. Cambridge, Cambridge University Press, 2018.

Woodcock E. C. A New Latin Syntax. Bristol Classical Press, 1959.

Zheltov A. Ju., Zheltova E. V. Why the language saves on the case forms, or about the order of cases in Latin. Indoeuropean Linguistics and Classical Philology 2020, 24, 1040-1069. (In Russian)

Received: July 31, 2020

Accepted: October 26, 2020 